Marja Clement*

\title{
The development of free indirect constructions in Dutch novels
}

\begin{abstract}
Why is the free indirect style such a useful narrative means to portray characters' minds in fictional texts? This article gives more insight into this phenomenon by analyzing texts from earlier times. Previous studies state that the free indirect style for the representation of thoughts emerged in Dutch literary prose in the 19th century. However, this article shows that the roots of this technique were already present in 17 th century Dutch popular literature novels. The analysis of these novels provides us with more insight into this phenomenon. Before the emergence of free indirect style, the most common form for the representation of a character's consciousness was direct discourse. The suggestion that the character is 'thinking out loud' makes this thought representation unnatural, as emotions and feelings are often pre-verbal and wordless. Free indirect style gives the narrator the possibility to formulate that which the character cannot put into words. The free indirect style allows the author to merge descriptions of events and actions with the character's inner life, feelings, questions and wishes without a change in the narrative style when it comes to personal pronouns and tense.
\end{abstract}

Keywords: free indirect style, early Dutch fiction, thought-representation

DOI 10.1515/jls-2014-0009

\section{Introduction}

We enter another world when we read a novel; we enter a world of other people's experiences. This is an attractive aspect of reading literature. Perhaps it is the most important characteristic of modern narrative fiction: the power to reveal the contents of minds (see Cohn 1978). Modern writers demonstrate a wide range of stylistic methods for representing and focalizing a character's psyche. Groundbreaking studies from Fludernik (1993), Palmer (2004) and Herman (2011) analyse the ways in which novelists construct characters' minds in fictional texts,

*Corresponding author: Marja Clement: Universität Zürich. E-mail: marja.clement@ds.uzh.ch 
and how readers follow the multifarious reflections, thoughts, memories, perceptions and emotions of characters in the story worlds of novels.

The use of free indirect constructions is one of the most intriguing means in narratives to focalize a fictional mind. This construction as a variant on the use of direct or indirect discourse is especially apt to portray a character. What makes this construction especially well suited for the representation of thoughts? This article will try to provide more insight on free indirect constructions by analyzing texts from earlier times. We focus on when and how the free indirect construction arose in Dutch literature.

Previous studies on the development of free indirect discourse (Van Gunsteren-Viersen 1980; Sicking 1989) state that the free indirect style for the representation of thoughts emerged in Dutch literary prose in the 19th century. However, this article will show that the roots of this construction are already present in 17th century Dutch popular, light-entertainment novels. An analysis of this early $17^{\text {th }}$ century will provide insight into the phenomenon and may explain the popularity of this style.

The free indirect style can be considered a form that is in between direct and indirect speech:

\footnotetext{
Direct discourse: He said: 'No, I don't remember this'

Indirect discourse: He said that he didn't remember that.

Free indirect discourse: No, he didn't remember this.

Direct thought: He thought: 'Where am I? Am I dreaming?'

Indirect thought: He wondered where he was and if he was dreaming.

Free indirect thought: Where was he? Was he dreaming?
}

As we can see in these examples, free indirect discourse represents the spoken words of a character and free indirect thought represents the thoughts of a character. In both cases the words or thoughts are presented indirectly, that is, not literally. Only in the direct form ('direct discourse' or 'direct thought') are the words or thoughts presented literally in the way they must have been uttered or thought. We also see in these examples that words and thoughts are presented free in free indirect discourse, which means that the discourse is presented in a main clause and not in a subordinate clause, which is the case for indirect quotes. This can be illustrated by the following fragments from the novel De ontdekking van de hemel (1992) 'The discovery of heaven' by Harry Mulisch. The story is about Quinten, a ten year old boy, who is fascinated with an imagined building, a castle, in which he often wanders around in his dreams. He is trying to find the building in pictures of architecture and art, but it doesn't seem to exist in reality. One day 
he visits professor Themaat, his neighbour, and suddenly he remembers his dream.

\begin{abstract}
'Trouwens, herinner je je nog dat boek van Bibiena, waar je vroeger zo graag in keek?' Nee, dat wist Quinten niet meer [...]

Toen hij het opensloeg, kreeg Quinten een schok. Bijna! Daar was hij bijna, zijn droom! Dezelfde, zich eindeloos naar alle kanten voortzettende ruimte vol trappen, bruggen, bogen, galerijen, de diepe schaduwen zonder lichtbronnen, alles gevuld met dezelfde roerloze lucht. (Mulisch 1992: 553)

'By the way, do you remember that Bibiena book, which you used to browse through so often?'

No, Quinten didn't remember that any more [...]

When he opened it, it gave Quinten a jolt. Almost! It was almost there, his dream! - the same rooms continuing endlessly in all directions, full of staircases, bridges, arches, galleries: the deep shadows without sources of light; everything filled with the warm still air. ${ }^{1}$
\end{abstract}

The sentence Nee, dat wist Quinten niet meer 'No, Quinten didn't remember that any more' does not provide a verbatim reproduction of Quinten's assumed actual words, neither are the words represented as if Quinten had said them out loud (which would have been the case if it was indirect speech: "Quinten said that he didn't remember that"). That is what makes this passage an example of free indirect discourse. And the sentence Bijna! Daar was hij bijna, zijn droom! 'Almost! It was almost there, his dream!' is an example of free indirect thought. Literally, the thought would have been in the first person, something like "Almost! There it almost is, my dream!". Another example can be found in the following fragment, from the same novel. Years later, when Quinten visits Rome together with the person whom he believes to be his father, he discovers something.

\begin{abstract}
Quinten keek naar de hangsloten, die hem nog niet waren opgevallen. Het bovenste was een reusachtig ijzeren ding, een schuifhangslot zo groot als een brood, - op het moment dat hij het zag, werd hij overweldigd door ontzetting. Waar was hij? Droomde hij? Was hij in zijn droom? Met grote ogen keek hij zijn vader aan. (Mulisch 1992: 748)

Quinten looked at the padlocks, which he hadn't noticed before. The upper one was a huge iron thing, a padlock as big as a loaf of bread, - he felt overwhelmed with dismay, the moment he saw it. Where was he? Was he dreaming? Was he in a dream? With big eyes he looked at his father.
\end{abstract}

In this fragment the questions Waar was hij? Droomde hij? Was hij in zijn droom? 'Where was he? Was he dreaming? Was he in a dream?' represent Quinten's thoughts. These thoughts are not presented literally, which would have looked

1 Translation from Dutch by Paul Vincent. 
like 'Where am I? Am I dreaming? Am I in a dream?', and also not indirect, with an introducing phrase like "he thought that ..." These are features of free indirect thought.

The main characteristic of free indirect thought is that we are not able to distinguish it from a regular narrative sentence message (a message which is not the representation of a character's thoughts) on purely grammatical grounds. In this respect the free indirect thoughts cannot be distinguished from the narrative text, because grammatically both are main clauses. Furthermore, the tense and person are adapted to the narrative text; if the story is told in third person imperfect, the free indirect thoughts would also have the form of the third person imperfect. The fact that this procedure is used so often in literary texts for representing thoughts raises some interesting questions. Although the use of the third person pronoun suggests that we are observing another person from the outside, we are diving into the consciousness of the character. How is that possible? (For the opposition between distance and nearness in relation to pronouns see also Levie and Wildschut, this issue.)

Why is this style so applicable for the representation of thoughts? This article tries to provide insight into this phenomenon by analyzing texts from earlier times. Section 2 sketches a corpus study on narrative techniques in Dutch literary prose throughout the ages. I will concentrate on 17th century novels. Section 3 shows that novels in the $17^{\text {th }}$ century represented the inner life if the characters usually with direct discourse. Section 4 then demonstrates that sometimes $17^{\text {th }}$ century authors made use of a preliminary form of free indirect thought. Section 5 shows that a full-fletched free indirect style sporadically occurs as early as the $17^{\text {th }}$ century, albeit rarely. Section 6 presents examples of the free indirect construction in 18th century novels. In conclusion, section 7 presents my answer as to why the free indirect construction is so well-suited for the representation of thoughts.

\section{Dutch literary prose through the ages}

I studied narrative techniques in Dutch literary prose throughout the ages, in order to find an answer as to why this construction is very appropriate for the representation of thoughts. This study was carried out by searching for the use of the first, second and third person pronoun in fiction and non-fiction in a large corpus of texts. One of the outcomes of this study is that the free indirect construction for the representation of thoughts emerged in Dutch literary prose in the 19th century, which is in line with previous studies on the development of free indirect discourse (Van Gunsteren-Viersen 1980; Sicking 1989). 
Free indirect style was used only sporadically in Dutch literary prose in 1840 (i.e. Bosboom Toussaint); since 1860 it emerged now and then in literary texts (i.e. Multatuli); from 1880 the construction becomes very popular (i.e. Couperus; Van Eeden), and it has never disappeared. Before the rise of free indirect discourse, the inner life, thoughts and feelings of characters was represented in three possible ways:

- Direct thought - for example: soliloquy

- Indirect thought

- 'Thought report' (Fludernik 1993): He didn't like that . . . / She felt that . . . It occurred to him ...

From the earliest medieval Dutch literature until the 19th century these were the main uses for representing characters' thoughts.

My corpus research suggests that the thoughts and feelings of characters are already represented in the earliest Medieval Dutch texts. These Medieval novels are third person stories, told by an authorial storyteller who dives into the consciousness of the characters. We see a remarkable change in this respect in the $17^{\text {th }}$ century when the first person novel becomes suddenly very popular. It should be noted that, in the Renaissance, these novels were considered low literature; only genres such as poetry and drama were deemed high literature. Nevertheless it can be interesting to study low, light-entertainment literature, because of the high popularity of these novels. Examples are a pastoral novel from Johan van Heemskerk, Inleydinghe tot het ontwerp van een Batavische Arcadia (1637) 'Introduction to the sketch of a Batavian Arcadian Novel', an anonymous hoofs-galante roman, 'courtly-gallant novel' Wonderlicke avontuer van twee goelieven (1624) 'The wonderous adventure of two lovers' and the schelmenroman 'picaresque novel' Den Vermakelyken Avanturier (1695) 'The entertaining adventurer' from Nicolaes Heinsius, to mention only some of the many available titles.

\section{Direct discourse in 17th century trivial novels}

The greatest part of these 17th century popular literature novels are first person stories. The main character tells his story - and almost always with the suggestion that the story comprises a real-life event.

Only some of these novels are third person stories told by an authorial narrator, a 'dramatized author', who is referring to himself using the first person, but who is not a character in the story. The most common form for representing a character's inner life is through direct discourse. For example, the pastoral novel Inleydinghe tot het ontwerp van een Batavische Arcadia (1637) is the story of 
Reynhert, who is passionately in love with Rosemond. He didn't sleep well the previous night, tormented by fearful thoughts and dreams. We get a glimpse into his feelings when he passes Rosemond's house in the following passage.

[A]ls de hopeloose Reynhert [... ] steegh vande logghe veeren, en komende met een verhaeste tret onder de groene Lindẽ van 't overschaduwde Voorhout, wierp een erbermelijck oog na de geslote vensters vande noyt-ghenoegh-ghepresene Rosemond; het oogh wierd strakx ghevolght van een sucht, en de sucht van dese woorden. Helaes! minnelijcke, doch minneloose schoonheydt, indien 't waer is dat meest alles aert nae de plaetse daer het is geteelt, hoe komt dan dat de soetigheydt van dit oversoete Voorhout $\mathrm{u}$ onverbiddelijck ghemoedt te mywaerts noyt heeft konnen versoeten? hoe kan 't wesen dat die vriẽdelijcke ooghjes (machtigh om door de stralen van een gunstigh lonckje de vervrosenste ziel te doẽ branden) souden sijn de qualijckvoeghende baeckens van een onbeweeghelijk hert? (Van Heemskerk 1637: 5-6)

When the desperate Reynhert had gotten up from his comfortable bed, and walked hastily under the green lime trees of shadowy Voorhout, he looked with eyes of misery at the closed windows of the highly esteemed Rosemond; A sigh followed his eyes, and the sigh was followed by these words. Alas! Lovable, but hard-hearted beauty, if it is true that almost everything resembles the place where it was grown, how is it possible that the sweetness of this honey-sweet Voorhout could never sweeten your inexorable heart towards me? How is it possible that those friendly eyes (powerful from the rays of a favourable glance to set on fire the most frozen soul) could be the stern markers of a motionless heart?

This thought monologue continues for three pages and ends with the following words:

Ist mogelijck, schoone, datmen met dienst ondanck by u behaelt? dat wel-willen weer-wil in u voortbrenght? en dat mijne liefde is moeder van uwen haet? Ist mogelijck dat al mijn lyden $\mathrm{u}$ niet en kan bewegẽ tot het minste medelyden? Ist mogelijck? en hier mede was 't den armen Herder on-moghelijck een enckel woordt meer uyt te brenghen: soo bedwelmt maeckte hem het overdenckẽ van haere uytnementheyt en van sijne onwaerdigheydt ... (Van Heemskerk 1637: 8)

Is it possible, my beauty, that courtesy causes your ingratitude? That kindness causes your unwillingness? And that my love is the mother of your hatred? Is it possible that all of my suffering cannot move you to the smallest compassion? Is that possible? And with this the poor shepherd was not able to express even one more word: he was so confused by thinking of her perfection and his disdainfulness.

As mentioned before, this long thought monologue of the desperately love-sick Reynhert is an example of direct thought. Notice that he speaks his thoughts out loud. That is a technique that was common in Medieval Dutch texts, and is still present in $17^{\text {th }}$ century popular literature. Often there is mention of deze woorden 'these words' or riep hij uit 'he cried out', or hij wilde voortgaan met dit gesprek 'he 
wanted to continue this conversation', which is evidence that the thoughts were really spoken out loud. Other support for this analysis is the frequency with which other characters report that they can hear the stream of thoughts of the speaking character, whether or not by chance. For example, in the love story collection of Baltes Boekholt, De wonderlijke vryagien en rampzaalige, doch bly-eyndige, trouwgevallen van deze tijdt (1668), 'The wonderful romances and disastrous, but happy ending love affairs of this epoch' we find in one of the love stories a long thought monologue by a female character, when she lays in bed at night. Her friend Narsisa, who is sleeping in the same room, comments on these 'thoughts', which suggests she is able to hear everything:

Ha! Arantus, sprak ze by haer zelfs; hoe blinken uw volmaektheden in 't binnenste van mijn ziel: hâ bitter ongeval! [. . .] Narsisa, die niet vast sliep, had zoo wel het eene als het andre gehoort [...] (Boekholt 1668: 24-25)

Ha! Arantus, she spoke to herself; how your perfections are sparkling inside my soul: hâ bitter misfortune! [...] Narsisa, who didn’t sleep steady, heard the first thing as well as the other [...]

The thought monologue from this female character is quite elaborate; it covers one whole page. All these thoughts are spoken out loud, while she is lying in bed at night, not able to sleep because of all the troubles occupying her mind. Modern readers may not consider it plausible that someone expresses such a long thought monologue out loud, lying in bed, but this is exactly the case here, as indicated by the reaction of the character's friend Narsisa.

The type of soliloquy is very common in Dutch narrative prose until the $19^{\text {th }}$ century. Sicking (1989) gives two explanations for its popularity. On the one hand people expressed their thoughts out loud also when they were alone. The psychological reasoning for this was that it was good to clear your heart, to voice all your problems, especially at moments of emotional stress. On the other hand, there is a literary necessity: a third person novel was written by a traditional, authorial narrator, and he could not look inside the mind of another person, any more than an ordinary person can. So the authorial narrator was like an observer, an eyewitness, and he wrote down the words he heard, when the character was expressing his feelings loudly.

Like previous studies from Anbeek (1978) and Van Gunsteren-Viersen (1980) stated previously, my study emphasizes that the emergence of free, indirect constructions in the $19^{\text {th }}$ century was correlated with the disappearance of the authorial narrator and the increased use of the neutral narrating technique. 


\section{A preliminary form of the free indirect style}

It is interesting to note that in the $17^{\text {th }}$ century the thoughts of characters were represented in a form that to some degree is similar to free indirect thought:

Arantus quellinge groeyde, na 't afzijn van Rosemont, meer en meer aen; daer hielp geen vriendens afradinge, welken hem wel aen een and're Juffer zouden hebben uitgehuwt, die van geen minder gelegentheydt dan Rosemont was; maer Arantus, te zeer vernibbelt op haer boven aertsche schoonheydt, en achten niet veel op hun reden: en hoe zoude hy zijn oogen op een and're konnen veste, in wiens boezem dat volmaekte beeldt van Rosemont gegrieft stondt, en hem alle dage met nieuwe hartstormen quam bespringen? 't was hem niet mogelijk om haer afzijn langer te dulden [...] (Boekholt 1668: 13)

'Arantus' torment grew more and more, after the absence of Rosemont; the advice of his friends did not help him; they urged him to marry another lady, just as special as Rosemont; but Arantus, who was yearning too much for her heavenly beauty, did not pay attention to their words: and how could he fix his eyes upon someone else when that perfect image of Rosemont was engraved in his chest, and made him burst with new heart storms every day? It was not possible for him to endure her absence any longer [... ]

We find Arantus' inner reasoning in the question hoe zoude hy zijn oogen op een and're konnen veste, in wiens boezem dat volmaekte beeldt van Rosemont gegrieft stondt, en hem alle dage met nieuwe hartstormen quam bespringen? 'how could he fix his eyes upon someone else ... new heart storms every day?'. This cannot clearly be labelled free indirect thought, although it has many similarities. It can be considered an emotional comment of the authorial narrator. The same can be said about the following passage, now seen from the perspective of Rosemont.

O zielroovende klachte! ô mins-prikkelende vonkken, die de boezem van Rosemont, als met een tintelent vuur verzengde! en haer hart zoodanig deě blaken, datze by na de eer aen een zijde zouw gestelt hebben, om Arantus quellinge door een daatelijke wedermin te verzachten. (Boekholt 1668: 27)

O heart-breaking complaint! ô titillating sparks, burning in Rosemont's bosom like a tingling fire! making her heart glow in such a way, that she almost put her honour aside, to relieve Arantus' torment with an immediate return of love.

This passage contains very emotional exclamations, reminiscent of free indirect thought. However, in this case the authorial narrator may be the one who is articulating the emotions that are overwhelming Rosemont, typical for this way of representing the emotions on the characters. Another example can be found in the following passage. Here we read Arantus' conflicting thoughts after he received a love letter from Rosemont. 


\begin{abstract}
Arantus werdt op dit leeze met zoo uytermate blijtschap bevange, dat hy byna door zodanige vreughde zoude gesturven hebbe: Hoe zal ik, sprak hy, liefkoozende, mijn engel nu omhelze, en haer mijn langdurige smarte verhale? maer ach! rampzalige Arantus; hoe zoude $u$ ooit zoodanigh geluk konnen gebeuren? neen, neen Arantus, en gewaerdicht u zoo veel niet waerdt te zijn; Rosemont doet dit om u te beproeve. Maer, ach lacy! voer hy voort; waerlijk verdiende mijn min zoodanige belooninge wel: Ach! dat het daghlicht wilde vertrekke, om mijn verlange te achterhale; daalt, daalt haestig, ô Phoebus! met u robijnkar, laat Tebus u omhelze, wijl Diana ter jacht is onder de planeete. Dus was hy als duldeloos, tot dat de zon zijn daghreys beneede 't Westen volbracht [...] (Boekholt 1668: 31)

After reading this, Arantus was overcome with so much happiness he could have died: How will $I$, he said, in adoration, embrace my angel now, and tell her about my long lasting sorrow? but ah! miserable Arantus; how could you ever receive such happiness? no, no Arantus, and don't you think you are worth so much; Rosemont is doing this to test you. But, ah alas! he continued; truly my love deserved such a reward: Ah! that the daylight would depart, to find out about my longing; decline, decline hastily, ô Phoebus! with your ruby cart, let Tebus embrace you, while Diana is hunting under the planets. As such he was restless, until the sun accomplished his day journey below the West [...]
\end{abstract}

Is Arantus talking to himself? See: maer ach! rampzalige Arantus; hoe zoude u ooit zoodanigh geluk konnen gebeuren? neen, neen Arantus, en gewaerdicht $u$ zoo veel niet waerdt te zijn; Rosemont doet dit om u te beproeve 'but ah! miserable Arantus; how could you ever receive such happiness? no, no Arantus, and don't you think you are worth so much; Rosemont is doing this to test you'. Or is it the authorial narrator's voice, not literally quoting Arantus' thoughts, but representing these thoughts by speaking to the character?

This construction was rather common in the 17 th century and may be considered as a preliminary form of free indirect thought, in which the authorial narrator is still clearly present. At the end of the 19th century the authorial narrator disappeared.

\title{
5 The emerging of the free indirect style
}

How we can explain the gradual emergence of the free indirect construction in the 19th century? Is it copied from other languages, for example English and French? Was it influenced by Jane Austen's Sense and Sensibility (1811) and Pride and Prejudice (1813) or Gustave Flaubert's Madame Bovary (1856), novels which contain an abundant use of the free indirect style?

Or could there be another explanation? Is it possible that the free indirect style was first used in non-fiction, and was adopted by narrative fiction? An indication for this can be found in a 17th century text, namely the novel Wonderlicke avontuer van twee goelieven (1624) (ed. E.K. Grootes 1988). This third person story 
is told by an authorial narrator and is about two lovers, Waterbrant en Wintergroen, who cherish a forbidden love, then lose sight of one another. Wintergroen, longing and yearning for her lover Waterbrandt, is wandering the wide world, disguised as a boy. One day a lieutenant and a soldier visit the hostel where she works as a servant, and Wintergroen is stunned to discover that the soldier must be Waterbrandt.

Winter-groen hem aen-siende, hoorende ooc sijnen naem noemen, scheen terstondt als stom te worden, ende den Nick makende, quam alsoo ter Deuren uyt: Doch daer niet langh vertoevende, pasten door de scheure vande Deur te sien, ofse in hare meyninghe niet bedroghen en was: Maer och neen sy, het was den gheenen daerom datse in so verre Landen ghedwaelt hadde, en daerom gheef ick die te bedencken die oyt Ghemint hebben, hoe dat haer hart ghestelt was, ende of sy niet meer en hadde te doen met t'overdencken, hoe ende in wat manieren dat sy de sake best openbaren mochte, als anders. (ed. Grootes 1988: 69)

Winter-groen, staring at him, heard his name, became silent, bowed and walked out the door: she did not stay there for a long time, she tried to look through a chink in the door to see if she was not mistaken: But oh no, it was the one for whom she had wandered around in far-away countries, and therefore I suggest to anyone who has ever been in love, to consider the condition of her heart, and whether she was not, more than anything else, thinking, how and in what way she could best divulge the situation.

The sentence Maer och neen sy, het was den gheenen daerom datse in so verre Landen ghedwaelt hadde 'But oh no, it was the one for whom she had been wandering around in such distant countries' can be regarded as free indirect thought; as the literal thought of Wintergroen, reproduced in the third person, past tense. So, while this form is found only sporadically, it does already occur in the 17th century.

\section{The representing of spoken words by the free indirect style}

There is more evidence to support the claim that free indirect constructions were already in existence before its emergence in the $19^{\text {th }}$. 18th century novels often contain free indirect discourse in the representation of spoken words .

Examples can be found in the novel Historie van Mejuffrouw Sara Burgerhart (1782), 'History of Miss Sara Burgerhart' from the authors Betje Wolff and Aagje Deken, considered as the first modern novel in Dutch literature. In this epistolary novel the free indirect construction is used for spoken words. In the following passage the character Sara Burgerhart writes to her friend Anna about a theatre 
performance. She had been accompanied by Lotje, who had really enjoyed the performance very much.

\begin{abstract}
Wy kwamen uit de Comedie direct t'huis, en de Heren namen in de zydkamer afscheid. Lotje is haar zelf niet van blydschap; zy is, zeit ze, nog nooit eens gevraagt, om in de Comedie te gaan; maar kyk, als zy nu veel geld hadt, dan ging zy er alle dag, zo mooi is 't in de Comedie. (Wolff and Deken 1782: 390)

We came home directly out of the Comedy, and the Men said goodbye in the side room. Lotje is besides herself from joy; she has, she says, never been asked to visit the Comedy; but look, if she were to have a lot of money, she would go there every day, the Comedy is that beautiful.
\end{abstract}

The sentence maar kyk, als zy nu veel geld hadt, dan ging zy er alle dag, zo mooi is ' $t$ in de Comedie 'but look, if she were to have a lot of money, she would go there every day, the Comedy is that beautiful' can be interpreted as the representation of Lotje's spoken words.

This specific use of free indirect constructions is very common in Dutch $18^{\text {th }}$ and $19^{\text {th }}$ century novels before 1880 . Another example can be found in the novel Fabriekskinderen (1863) 'Factory kids' by J.J. Cremer. This novel is written in the present tense. The narrator is a real authorial narrator, who is not a character in the story, but who is nevertheless speaking in the first person and is often addressing the reader. The reader is taken by the hand to look, as an observer, to the poor and miserable conditions of life of the factory workers and their children. The rich man Willem van Hogenstad finds a child on the street, laying on the sidewalk, more dead than alive. He is concerned about the fate of the poor and he carries the child to his house. He gives it food, and warm clothes. The next day he has the following conversation with the child.

'En ga je ook school?’ vraagt Willem weder, na een oogenblik van sombere stilte. [.. .] Neen, naar school gaat hij niet.

Naar school kan hij niet gaan, want dertien, veertien, ja vijftien uren moet hij werken - staande werken, op éénen dag.

Naar school gaat hij niet, want het dagloon zou dan minder worden en voor vader en moeder te schadelijk zijn.

Boeken? Neen, boeken heeft hij nooit gezien.

Ja! als dát daar tegenover hem, boeken zijn, dan weet hij 't wel: dat zijn bijbels; moeder heeft er ook zoo een, en ze zeit: 'en dominés bedrieger.

Wat een dominé is? Dat weet hij niet. Of, ja, die woont in de kerk.

En wat de menschen zondags gaan doen in de kerk? dat kan hij niet zeggen; want hij is er wel in geweest, maar heeft toen geslapen. (Cremer 1863: 28-29)

‘And do you also go to school?’ asks Willem again, after a moment of sombre silence. [...] No, he doesn't go to school.. 
He cannot go to school, because he has to work thirteen, fourteen, yes fifteen hours - on his feet, every day. He doesn't go to school, because the wages would diminish and that would harm his Mum and Dad.

Books? No, he has never seen books.

Yes! if those things facing him are books, then he knows what they are: those are bibles; Mother also has one, and she says: the preacher is an imposter.

What a preacher is? That he doesn't know. Or yes, he lives in the church.

And what do people do in church on Sunday? that he can't say; because he was there once, but he had slept.

The answers of the child are for a large part reproduced in a free indirect construction. The clearest examples are the sentences Boeken? Neen, boeken heeft hij nooit gezien 'Books? No, he has never seen books', Wat een dominé is? Dat weet hij niet. Of, ja, die woont in de kerk 'What a preacher is? That he doesn't know. Or yes, he lives in the church' and En wat de menschen zondags gaan doen in de kerk? dat kan hij niet zeggen; want hij is er wel in geweest, maar heeft toen geslapen 'And what do people do in church on Sunday? that he can't say; because he was there once, but he had slept.'

\section{Why is the free indirect style so special?}

It is not until 1880 that we see the use of the free indirect construction for the reproduction of characters' thoughts in Dutch literature on a large scale. Generally speaking, we can say that the free indirect style could emerge in the 19th century because of the disappearance of the authorial narrator and the appearance of a more neutral narrating technique. This raises another intriguing question. Free indirect discourse seems to mix the narratorial discourse with the protagonists' utterances or thoughts. The question is whether it should be considered a mix of two voices, a dual voice, the character's voice and the narrative voice (Brillenburg Wurth and Rigney 2008; Herman and Vervaeck 2005; also see Maier, this issue) or whether there is another way of describing and explaining the phenomenon.

What makes the free indirect style so special? Why is this style so well suited for the representation of thoughts? What makes it so appropriate for the representation of feelings, thoughts and experiences of characters in a story? Let's consider again the quotes from Harry Mulisch's modern novel De ontdekking van de hemel (1992) 'The discovery of heaven'. An important characteristic of the free indirect style is that the content of the expression comes from the character, although the expression cannot literally be an utterance originating from the character. Quinten's literal thought might have been something like this: 'It is a secret and I will not talk about it with anybody'. The representation is not literal; a 
change occurred in tense and/or personal pronoun in the original expression or reasoning. Het was een geheim en hij mocht er met niemand over praten 'It was a secret and he could not discuss it with anybody'. There is no explicit specification whether it is an utterance or a thought, an important characteristic of the free indirect style. So when we read Nee, dat wist Quinten niet meer 'No, Quinten didn't remember that any more', we don't know whether Quinten says this or only thinks this, without voicing it out loud.

We are not able to distinguish free indirection constructions from ordinary narrative texts on purely grammatical grounds. The consequence is that narrative text and interior monologue can easily merge. 'When he opened it, Quinten was shocked' (this is narrative text) 'Almost! There it was, almost his dream!' (interior monologue). Without losing the narrative form, there is an easy alteration between description of visible events, actions and experiences, and the character's inner feelings, questions, and wishes. This makes it clear why this form is preferable over the indirect discourse. A disadvantage of the indirect discourse is, that for longer parts of consciousness representation the repetition of 'she thought that' or 'he supposed' is disturbing; the indirect discourse is more fitting for the summary or recapitulation: an elaborate reasoning is summarised in a few sentences.

The free indirect form also has advantages over direct discourse. Emotions and feelings are often pre-verbal, wordless, sometimes even unconscious. The free indirect construction gives the narrator the possibility to formulate that which cannot be put into words by the character. The direct discourse suggests that the character is 'thinking out loud' and that makes thought representation unnatural. In reality we don't think in full sentences. Maybe we don't even think in words. Often our thoughts, feelings, emotions are wordless. It is possible that free indirect constructions are so appropriate for the representation of feelings, thoughts and experiences because of these two important features: the narrative form can easily be continued and feelings, emotions and thoughts, which the character cannot put into words, are formulated for the reader. (See also Blok 1960; Bal 1986; Van Luxemburg et al. 1987; Bronzwaer et al. 1977; Van GunsterenViersen 1980; Van der Voort 1986.)

\section{Conclusion}

Why is the free indirect style so appropriate for the representation of thoughts? Can we gain more insight in this phenomenon by analyzing Dutch texts from times when this style did not yet exist? Corpus research shows that from the Middle Ages until the 19th century the direct discourse or soliloque was very 
common. Only with the disappearance of the authorial narrator and the emergence of the neutral narrating technique, the free indirect style could emerge in the 19th century. But already in the 17th century there is a sporadically use of the free indirect style, besides a more common preliminary form. This phenomenon and the use of free indirect style for spoken words in 18th century novels is maybe a cautious indication that the free indirect style was possibly an already existing form.

Some important questions remain unanswered. The free indirect style is a common form in contemporary language usage, also in nonfiction, in written texts as well as in spoken language (Haeseryn et al. 1997: 1099). Is there a difference between the use of this style in fiction compared to nonfiction? Was the free indirect construction in earlier centuries first used in nonfiction, and did it only appear in fiction with a new use? Or is this style as a literary procedure for representing characters thoughts copied from literary examples from surrounding countries, for example from France, England and Germany? Or should we look at combinations of these factors? Further research is necessary.

\section{References}

[Anonymous] 1624. Wonderlicke avontuer van twee goelieven [The wonderous adventure of two lovers]. Edited by E.K. Grootes 1988. Muiderberg: Dick Coutinho.

Anbeek, Ton. 1978. De schrijver tussen de coulissen [The writer in the side wing]. Utrecht: Dissertation.

Bal, Mieke. 1986. De theorie van vertellen en verhalen: Inleiding in de narratologie [Narration (Rhetoric)]. Muiderberg: Coutingho.

Balk-Smit Duyzentkunst, Frida. 1983. Getransformeerde directe rede en toch geen indirecte rede: Over de grammatica en poetica van Judith Herzberg [Transformed direct discourse and still not indirect discourse: About Judith Herzberg's grammar and poetry]. Forum der letteren 24, 277-289.

Bernaerts, Lars, Carl de Strycker \& Bart Vervaeck. 2011. Breuken en bruggen: Moderne Nederlandse literatuur: hedendaagse perspectieven [Breaks and bridges: Modern Dutch literature: Contemporary perspectives]. Gent: Academia Press.

Blok, W. 1960. Verhaal en lezer: Een onderzoek naar enige structuuraspecten van 'Van oude mensen, de dingen die voorbij gaan' van Louis Couperus [Narrative and reader: research into structural aspects in 'Van oude mensen, de dingen die voorbij gaan' van Louis Couperus]. Groningen: Wolters-Noordhoff.

Boekholt, Baltes. 1668. De wonderlijke vryagien en rampzaalige, doch bly-endige, trouwgevallen van deze tijdt, tusschen Arantus en Rosemondt. Grannadus en Cielinde. Coredon en Leliana. Fierandus en Leonora. Herkelus en Narsise. Voorgevalle in het roem-ruchtigh Hollandt, herwaerts inj weynigh jaeren [The miraculous woes and disastrous, although well-ending loves stories of today, between Arantus and Rosemondt. Grannadus and Cielinde. Coredon and Leliana. Fierandus and Leonora. Herkulus and Narsise. Events in renowned Hollandt, over a few years]. Amsterdam. 
Van Boven, Erica \& Gilles Dorleijn. 2003. Literair mechaniek: Inleiding tot de analyse van verhalen en gedichten [literary mechanisms: Introduction to the analysis of narratives and poems]. Bussum: Coutingho.

Brillenburg Wurth, Kiene \& Anne Rigney. 2003. Het leven van teksten: Een inleiding tot de literatuurwetenschap [life of texts: an introduction to literary science]. Amsterdam: Amsterdam University Press.

Bronzwaer, W., D. Fokkema \& Elrud Kunne-Ibsch. 1977. Tekstboek algemene literatuurwetenschap [Textbook general literary sciences]. Baarn: Ambo.

Bru, Sascha \& Anneleen Masschelein. 2006. Tijding en tendens: Literatuurwetenschap in de Nederlanden [News and trends: Literary sciences in the Netherlands]. Gent: Ginkgo / Academia Press.

Cohn, Dorrit. 1983. Transparent minds: narratives modes for presenting consciousness in fiction. Princeton, New Jersey: Princeton University Press.

Cremer, J. J. 1863. Fabriekskinderen [Factory kids]. Arnhem: Thieme.

Fludernik, Monika. 1993. The fictions of language and the languages of fiction. London: Routledge.

Van Gunsteren-Viersen, Julia. 1980. De vrije indirect rede: Theorie en ontwikkeling [Free indirect discourse: theory and development]. Forum der letteren 21(4), 266-282. Muiderberg: Coutingho.

Haeseryn, Walter J. M., Kirsten Romijn, Guido Geerts, Jaap de Rooij \& Maarten C. van den Toorn. 1997. Algemene Nederlandse Spraakkunst, 2nd ed. Deurne: Wolters Plantyn, http:// ans.ruhosting.nl/e-ans/index.html. (4 June, 2014.)

Van Heemskerk, Johan. 1637. Inleydinghe tot het otnwerp van een Batavische Arcadia [Introduction to the design of a Batavarian Arcadia] Amsterdam: Gerrit Jansz.

Herman, David. 2011. The emergence of mind: Representations of consciousness in narrative discourse in English. Lincoln: Nebraska University Press.

Herman, Luc \& Bart Vervaeck. 2005. Vertelduivels: Handboek verhaalanalyse. [Narrative devils: textbook narrative analysis]. Nijmegen: Vantilt.

Leech, Geoffrey \& Mick Short. 1981. Style in fiction: A linguistic introduction to English fictional prose. London: Pearson Education.

Van Luxemburg, Jan, Mieke Bal \& Willem Weststeijn. 1987. Over literatuur. [About literature]. Muiderberg: Coutingho.

Missine, Lut. 2013. Oprecht gelogen: Autobiografische romans en autofictie in de Nederlandse literatuur na 1985. [Sincere lies: Autobiographical novels and autofiction in Dutch literature after 1985]. Nijmegen: Vantilt.

Mulisch, Harry. 1992. De ontdekking van de hemel [The discovery of heaven]. Amsterdam: De bezige bij.

Palmer, Alan. 2004. Fictional minds. Lincoln: University of Nebraska Press.

Sicking, J. M. J. 1989. Bewustzijnsweergave in Nederlandse romans uit de negentiende eeuw [Representations of consciousness in Dutch 19th century novels]. De nieuwe taalgids, 82(4), 289-304. Groningen: Wolters-Noordhof.

Schlenker, Philippe. 2004. Context of thought and context of utterance: A note on free indirect discourse and the historical present. Mind and language, 19(3), 279-304.

Van der Voort, Cok. 1986. Hoe vrij is de vrije indirecte rede? [How free is free indirect discourse?] Forum der letteren, 27(4), 241-255.

Wolff, Betje \& Aagje Deken. 1782. Historie van mejuffrouw Sara Burgerhart [History of Miss Sara Burgerhart]. 